\title{
Language Management in "International” Pentecostal Churches in Cameroon
}

\author{
Jean-Paul Kouega \\ University of Yaounde I, Yaounde, Cameroon \\ Email: jkouega@yahoo.co.uk
}

How to cite this paper: Kouega, J.-P. (2018) Language Management in "International" Pentecostal Churches in Cameroon. Open Access Library Journal, 5: e4646. https://doi.org/10.4236/oalib.1104646

Received: May 7, 2018

Accepted: May 28, 2018

Published: May 31, 2018

Copyright (c) 2018 by author and Open Access Library Inc.

This work is licensed under the Creative Commons Attribution International License (CC BY 4.0).

http://creativecommons.org/licenses/by/4.0/

\begin{abstract}
This paper considers Pentecostal churches whose names include such globalising terms as "all nations", "global", "international", "universal" and "world", with a view to uncovering the nature of their language management, as it has not been made explicit in any document. The data come from some 35 churches located in various residential areas of the city of Yaounde. In each church, five members were contacted i.e. one pastor, one church official, one choir leader and one male and one female congregants. The instruments used were a questionnaire, informal discussions, interviews and participant observation. A total of 40 highly motivated research assistants were involved in the data collection process, which took place in January and February 2016. The framework used for the analysis was the structural-functional model. The analysis revealed that the services of these churches contained four to 13 parts and that the languages used to realise these parts were French and English, with translation from one language to the other being systematic. When tongue speaking was used, translation was not done. During Testimonies, congregants not sufficiently competent in French or English occasionally switched to Pidgin or a few Cameroonian languages. Most of these churches were found not to be represented in other countries outside Cameroon and those that were said to use English singly or in combination with other languages, not with French.
\end{abstract}

\section{Subject Areas}

Education, Linguistics

\section{Keywords}

Cameroon, Pentecostal Churches, Language Management in Religion, Multilingualism, Language Choice, Tongue Speaking 


\section{Introduction}

For some years, a number of Pentecostal churches in Cameroon have changed their names, adopting new names that usually contained globalising terms like "all nations", "global", "international", "universal" and "world", which are subsumed in this work by the term "international". The purpose of the present study is to look into the language policy of these "international" churches, which has not been made public in any document. As Spolsky ([1], p. 8) recommended, the nature of the language policy of such institutions "must be derived from a study of their language practices". There is a need to examine these practices in order to work out the processes underlying language management in these churches. This investigation is guided by a set of four interrelated research questions: 1) As these churches share a term in their names, what elements of worship service structure do they also share? 2) What languages are chosen in Cameroon to realise these elements and what factors determine the choice of these languages in the multilingual context of Cameroon? 3) What languages are chosen in similar churches in other countries to realise these same elements? 4) What does the term "international" in the names of these churches mean? In other words, does the use of the term "international" influence language management in the practices of these churches? The work is divided into four sections labelled: background to the study, review of literature, methodology and, lastly, analysis and discussion. These are considered in turn.

\section{Background to the Study}

The situation of languages in Cameroon and that of Pentecostal churches in this multilingual country are considered in turn. Cameroon has a very high number of ancestral languages which have not even been counted by Government. Figures ranging from 120 to close to 300 have been put forward by various researchers (see Dieu and Renaud [2], Chia [3], Bitjaa-Kody [4], Kouega [5], Lewis et al [6], where these languages are listed). These languages are spoken natively by some 20 million people, with some languages used by a few score of people and a handful by close to 400,000 . Three major lingua francas span three or more of the ten regions of the country. These are: Fulfulde which covers the three northern regions of the country, Pidgin English which is dominant in at least four south-western regions and the Beti language group which covers at least three south-eastern regions; one speech form created by educated youngsters aged between 15 - 50 today and referred to by linguists as Camfranglais (Kouega [7]) is spoken across the national territory. Lastly, two languages namely French and English, have official status and are therefore used for government transactions. (See Kouega [5] for an extended description of the language situation in Cameroon.)

Regarding Pentecostal churches in Cameroon, there is very little documentation on them. While Catholic and Protestant churches-which may be referred to as mainstream churches here-were planted in the country in the colonial 
days, Pentecostal churches came after independence in 1960. They recruited their faithful from two major sources: the mainstream churches and the pool of animists. Actually all Cameroonian ethnic groups had been worshiping God before colonisation started and this same God is still worshiped today on week days while Sundays are reserved for church worship by a handful of people. Pentecostalism soared in the 1990s when Cameroon was seriously hit by a devastating economic crisis. Civil servants' salaries were reduced to barely $30 \%$; bankers had to reschedule bank loans; worse the CFA Franc-the Cameroon currency-was devalued, which caused serious social unrest. It was at the peak of this crisis that impoverished people heard of pastors who could heal with mere prayers, who preached prosperity, who could perform miracles, who could break the yoke of bondage by simply quoting a verse from the Bible, who could make barren couples have babies, who could deliver people from demonic dens and who could make predictions accurately. Weeks upon weeks, scores of people who claimed to have received divine blessings stood up in church to testify. Many people went to church to see for themselves what they had been hearing around them. People whose families were disintegrated because of the economic crisis found a new family in church, as most devotees referred to one another as brothers and sisters of the same family. The situation today seems to have changed.

\section{Review of Literature}

A number of scholars have worked on language management and language use in religious contexts. Language management is an orientation within language policy and planning as understood by researchers like Kaplan, Shohamy, and Spolsky. To Kaplan ([8], p. 925), "a language policy is a body of ideas, laws, regulations, rules and practices intended to achieve the planned language change in the society, group or system". Unfortunately, there are situations where this policy may be hidden or realised through various covert mechanisms. As Shohamy ([9], p. 53) pointed out:

It is often the case that formal language documents become no more than declarations of intent that can easily be manipulated and contradicted. Yet, it is essential that these mechanisms, or policy devices... must be included in the general picture for understanding and interpreting LP (language policy).

This means that, when language policy is not laid down explicitly in a document, it must be worked out implicitly by observing the various de facto practices used in the society. To Spolsky [1] [10] [11], language management, an aspect of language policy which takes up what was earlier known as language planning, deals with how individuals in a speech community "choose what language to speak under what circumstances and for what purposes." Language managers are understood as individuals, a special interest group, an institution or business, the government, schools, a legislative assembly, etc. Language choice is said to be determined by three conditions known as practice, beliefs and 
management. Language practice, the first condition, refers to "what people actually do with language". Beliefs about language, the second condition, are said to be values or statuses that the speech community associates with its language products, be they languages, language varieties, or language features such as accents, not economic benefits. As for language management, the third condition, it is "the explicit and observable effort by someone or some group that has or claims authority over the participants in a domain (e.g., family, work, etc.) to modify their practices or beliefs". The present study examines the language choices that language managers in church, i.e., pastors, make in a highly multilingual context where no regulations are written down explicitly and where various covert mechanisms are used to influence the language use of groups of individuals, i.e., the faithful.

Regarding language use in religious contexts, sociolinguists like Kouega [12], Kouega and Ndzotom [13], Kouega and Baimada [14] have examined the situations in Catholic and Protestant churches and in the Islamic faith, all using the structural-functional model of analysis outlined in Kouega [12]. This researcher worked on language management in 20 of the 65 parishes of the Catholic Church in the city of Yaounde and found that four liturgical languages-French, Beti, English and Basaa were used, with French being by far the dominant languages, obviously because the area of study was located in francophone Cameroon. English was used in Anglophone masses in a few parishes, and Beti, i.e., a language group name represented by Ewondo, and Basaa were used singly or in conjunction with French in some parishes. As for Cameroon minority languages, they were found to be used in all the parishes observed, with Bamileke languages featuring more frequently, Bamileke being a language group name. While liturgical languages could be used for all activities in a mass-Gospel, sermon, Eucharist, etc.-minority languages were used mainly for singing and occasionally for epistle reading. Language choice in a parish seemed to be determined by a variety of factors, the dominant one being the degree of involvement of a community of speakers in church issues (cleaning of the church premises, financial contributions, active participation in masses, etc.)

A related study was conducted in Ghana, where Albakry and Ofori [15] described language use at Catholic Masses and in informal social interactions by worshippers in Accra, the capital of Ghana, using Myers-Scotton's [16] [17] theory of matrix language frame. They observed ten churches in Accra and audio-recorded their services. Particular attention was paid to when and how English was employed monolinguistically and in combination with indigenous languages. Emphasis was laid on whether priests spoke English throughout the Mass (including homilies), code-switched and/or code-mixed, or had somebody else translate their English utterances into the main local languages spoken in Accra, namely, Ga, Akan-Twi/Fante, Ewe, and Haoussa. They identified five major parts in a church service, namely, the introduction, Bible readings, homilies, Prayers of the faithful, and Announcements. It was found that the introduc- 
tion of Masses in the corpus was in English. Bible passages were first read in English and, then, in at least one of the dominant indigenous languages in Accra. Homilies were done in English only in 50 per cent of the churches surveyed; in the remaining churches, both English and the local languages were used, with homilists either speaking monolinguistically, or code-switching and code-mixing. Occasionally, the homilists spoke in English and consciously switched to a local language to repeat what they had already said. The Prayer of the faithful was conducted mainly in English (80\%) in most churches, and was delivered in both English and the local languages (20\%) in a few churches. Lastly, Announcements were made in English in churches located in upper-class neighbourhoods (30\%) and in English and the local languages in churches located in both middle-class and lower-class areas (70\%).

Kouega and Ndzotom [13] considered language practices in one Protestant Church in Cameroon, the Presbyterian Church. Two parishes of this church in the city of Yaounde were visited and the analysis of the data collected showed that the dominant languages used in this church in Yaounde were English, French and Basaa. Besides, eight other languages, i.e., one foreign languageLatin-and seven ancestral languages-Akoose, Bulu, Duala, Kenyang, Lamnso', Meta and Mungaka-were used in the parishes. The languages were found to be chosen for a variety of reasons including the historical background of these churches in Cameroon, the numerical weight of a group of faithful in a given parish and the degree of involvement of a given ethnic group in church activities.

Kouega and Baimada [14] took up language management in the Islamic faith. The study was conducted in the main mosque in the city of Maroua, the headquarters of the Far North region of Cameroon, where a series of Friday congressional prayers were observed. The analysis of the data thus collected revealed that Arabic was the dominant language used, which could be guessed. What was new was that one other language was used exclusively for sermons and announcements; it was Fulfulde, a widespread northern Cameroon lingua franca. The choice of these languages was found to be determined by a variety of factors: Arabic was the liturgical language associated with Islam while Fulfulde was the language of the Imam, that of the Muezzin and a vehicular language in the neighbourhood.

Afutendem [18] examined language choice in three dominant Christian denominations in the city of Bamenda, the headquarters of the Northwest Region, i.e., the Roman Catholic Church, the Presbyterian Church, and the Full Gospel Church. The research was guided by three key questions, namely: 1) What are the elements of structure of a service in each of these churches? 2) What are the languages used to realise each element of structure? and 3) What factors determine the choice of the languages used in church out of a multitude of available languages? The analysis revealed many interesting points. First, there were 14 key elements in the Catholic Church service, 13 in the Presbyterian Church ser- 
vice and 6 in the Full Gospel Church service i.e. a total of 33 elements for the three churches. Second, English was found to be the dominant language as it was used in all the 33 elements (100\%). Pidgin co-occurred with English in $27.27 \%$ of the 33 elements while French co-occurred with English in 9.09\%. In-between these elements were songs that were sung in English and French (which are Cameroon's official languages), in Kom, Lamnso' and Ngemba (which are Cameroon's indigenous languages spoken in the area), Pidgin English (a dominant lingua franca spoken in the area) and Lingala and Swahili (two dominant lingua francas in the southern half of Africa). Third, several factors were found to determine the choice of these languages: they were the official language of the locality or a lingua franca used to ease communication between the literate and the illiterate in the locality. Incidentally, a language was used when there were lively hymns that were composed in it like Lingala, and when its speakers were active choir members like the Kom or Lamnso' people.

Kouega [19] dealt with one Pentecostal Church-a sub-group of Protestant churches-known as the Full Gospel Mission Cameroon (FGMC). The data came from some 80 pastors, church officials, choir leaders and congregants, and the settings were some 20 churches located in two anglophone regions and two francophone regions of Cameroon. The instruments used were a questionnaire, informal discussions and interviews, and participant observation, and the framework adopted for analysis was the structural-functional model. It was found that an FGMC service contained 4 - 13 parts and that the languages used to realise the bulk of these parts were French and English. Occasionally, several other languages and language-like forms, like tongue speaking, were heard in two specific parts, namely Testimonies and Ministration. French and English were used because the congregants were expected to be educated in either French or English and the translation services were systematically offered so that no group of faithful is left behind. Testimonies were made in any language chosen by the speakers and translations were usually offered in French or English, depending on the usual language of expression of the officiating pastor. The ongoing study focuses on one sub-group of Pentecostal churches, using this same framework of analysis. These churches were chosen because they have a common name and it is wondered whether they also apply common language management principles. The present article attempts to fill this gap in knowledge.

\section{Methodology}

The setting of the study, the informants, the instruments and the method of data collection are outlined here. The investigation took place in the city of Yaounde. It was conducted by a researcher assisted by 40 highly motivated assistants who were language and sociolinguistics students practising other faiths including Animism, Catholicism and Mainstream Protestantism. These research assistants were taught how to segment a church service, drawing from video-recorded materials. Then they rehearsed the acquired skill in a crowd-pulling worship service of the Full Gospel Mission Cameroon (see Kouega [20]). After this, they were 
given the means to tour the city of Yaounde and identify the targeted churches, i.e., churches whose name contained a globalising term like "all nations", "global", "international", "universal" and "world". The list is in Appendix A. Some 35 churches located in various parts of the city of Yaounde were thus identified. It is not clear whether this list is exhaustive: some are not registered and new ones can come up any time. The paper therefore takes these 35 churches as the research object. Concerning the informants, five members of each identified church were contacted, i.e., one pastor, one church official, one choir leader and two congregants, one male and one female. To successfully interact with these people, each research assistant had to visit their church between three to five times and attend a full church service at least twice. Training was done in December 2015 and data collection took place in January and February 2016. The research being ethnographic in nature, each research assistant was assigned to attend the service of one church, and two were sent to churches whose services were found to potentially last for more than four hours. Each of the pastors gave their oral consent and, in addition, they helped to choose the four other informants to contact; in other words, the informants did not know what the data collected was to be used for but the pastor, who proposed these informants, did. Actually, a summary of the information obtained from the five informants in each church was read out to the pastor. Regarding the instruments used, they included a 12-item questionnaire which was designed after two or more sessions of participant observation, interviews and informal discussions with the selected informants (see Appendix B).

The method of data collection was clearly outlined. During their initial contact with a pastor in the premises of a targeted church, the research assistants were to copy or film pieces of information pasted on walls or contained in flyers handed over to visitors. These pieces of information generally included church programmes, week schedules, announcements and the like. Then, the research assistants were to go back to the church premises at a time when they could meet the targeted informants. Working sessions were arranged during which various techniques including interviews were used to collect as much information from these informants as possible. Next, drawing from the information gathered by the assistants, the researcher designed a questionnaire to facilitate quantification. Finally, research assistants sat through a complete worship service, and immediately after the service, they assisted each selected informant with filling in the questionnaire, with the pastors occasionally interacting with other selected informants who were waiting. It should be noted that several activities go on after a church service and one really needs to be patient to get the selected informants. As five informants were to be contacted in each of the 35 churches identified, a total of 175 questionnaire returns were gathered, giving a $100 \%$ response rate achieved thanks to patience.

\section{Analysis and Discussion}

The first question (Q1) asked the 175 informants to indicate how many chapels 
of their church there were in the city of Yaounde and the numbers reported ranged from five to one: the Winners' Chapel International was said to have five, the Vraie Eglise Internationale de Dieu du Cameroun had four, the Light World Mission International had two, and the Triumphant Ministries International had one. Usually, different numbers were given by each informant. Actually it is difficult to tell how many churches there are in a town, as some of these churches are still to complete the process of registration.

Q2 enquired about the hierarchical structure of the church i.e., whether there was a supervisory body above and below the resident pastor. From the answer to this question, one could make a guess to the answer to Q7 below.

As Table 1 shows, $85.71 \%$ of 175 informants drawn from the 35 churches reported that there was no supervisory body above their resident pastors. Usually, the pastors were the founders of the churches and were therefore the highest figures. The informants from a few churches (14.29\% of 175) reported that there was a body above the pastor. One of them, Winners' Chapel International, was said to have a powerful supervisory body above the pastors. Bishop David Oyedepo, the founder of this church, was said to be based in Nigeria and is the president of the church. Next below the president are: the assistant president, the executive secretary, the regional overseer who takes care of all the churches in a region like Central Africa or an entire state in Nigeria, the national overseer who supervises the church activities in one country like Cameroon, the provincial pastor who looks after the churches in part of a country. There are five such provincial pastors of this church in Cameroon. The last position was said to be occupied by the resident pastor, who is helped by a pastoral assistant. In churches where the pastor was the highest figure, the hierarchical structure included the pastor, the deacons, the elders, the Sunday school teachers, the choir leaders and the faithful. Incidentally, some informants said that the Nigerian prophet T. B. Joshua was the highest figure of their church and the young Cameroonian prophet was simply representing T. B. Joshua in Cameroon. They added that their worship services begin with captivating televised episodes of the latest deliverance sessions at the T. B. Joshua's Synagogue Church of All Nations (SCOAN) in Nigeria.

Q3 asked the informants to name other countries where branches of their churches existed, with the assumption that if a church was represented in one country only, it could not be termed "international". The result is displayed in Table 2.

As Table 2 shows, $57.14 \%$ of 175 informants reported that their churches had no representation outside Cameroon and in many cases, outside the city of Yaounde. These churches constituted the bulk of those which were said not to

Table 1. Supervisory bodies above and below the pastor in the churches.

\begin{tabular}{ccc}
\hline Supervisory body above the pastor & Supervisory body below the pastor & Total \\
\hline 25 & 150 & 175 \\
$14.29 \%$ & $85.71 \%$ & 100 \\
\hline
\end{tabular}


Table 2. Number of foreign countries where branches of a given church are found.

\begin{tabular}{ccccccc}
\hline $\begin{array}{c}\text { Number of } \\
\text { countries }\end{array}$ & 0 & $1-2$ & $3-4$ & 5 and above & Blanks & Total \\
\hline Informants & 100 & 20 & 10 & 15 & 30 & 175 \\
& $57.14 \%$ & $11.43 \%$ & $5.71 \%$ & $8.57 \%$ & $17.14 \%$ & 100 \\
\hline
\end{tabular}

have a supervisory body above the pastor in Q2 above. As many as $17.14 \%$ of 175 informants skipped the question, despite the various attempts made by the research assistants to reformulate it. Some $11.43 \%$ of 175 cited one or two countries like Ghana and Ivory Coast and $5.71 \%$ cited three or four countries like Ghana, Nigeria, Togo, and the USA. Lastly, $8.57 \%$ of 175 informants reported that their churches were in five and more countries. Actually, the following churches-Winners' Chapel International, Christian Missionary Fellowship International, Faith Covenant Ministry International, and Universal Church of the Kingdom of God-were said to be found in several countries in all continents.

Q4 asked whether these informants had the addresses of their churches in any two or more countries. Most informants could not provide the addresses except those from the churches which claimed to be represented in five countries and more listed in Q3 above. Q5 inquired whether their pastors organised meetings with other pastors of their churches, be they monthly or annually, with the aim to check what languages these pastors use in such encounters. It turned out that the bulk of the pastors did not organise meetings with other pastors of their churches. However, the pastors of churches with a high international representation cited in Q2 above were reported to organise regular meetings and annual congresses. Q6 asked whether worship services were conducted in all countries in the same way and in the same languages and most informants said the structure of the services differed but the goals were the same i.e., "Go therefore and make disciples of all the nations, baptizing them in the name of the Father and of the Son and of the Holy Spirit...” (Matt 28:19). Some informants reported that in Nigeria, English was used in some churches while English and Yoruba were used in others. Similarly, English and Lingala were said to be used in Congo. This finding answered the third research question.

Q7 asked the informants to explain what the terms "all nations", "global", "international", "universal" or "world" in the name of their churches meant to them (Table 3).

To most informants including pastors of churches with a high international representation (85.71\%), "international" meant that if they left Cameroon and settled anywhere in the world, they would find their churches. To the pastors of churches planted only in Cameroon (14.29\%), "international" meant that their churches welcome believers of all nations, be they Black or White, European or Asian. In other words, there is a mismatch between what some pastors think about the "international" nature of their churches and what their faithful think.

Q8 asked about the duration of an ordinary worship service in the informants' churches and it was reported that a service lasts for two hours in some churches and as many as six hours in others. Some informants said that in their churches, 
Table 3. Meaning of the term "international".

\begin{tabular}{ccc}
\hline Church found in all countries of the world & $\begin{array}{c}\text { Church welcoming members from all } \\
\text { countries of the world }\end{array}$ & Total \\
\hline 150 & 25 & 175 \\
$85.71 \%$ & $14.29 \%$ & 100 \\
\hline
\end{tabular}

the starting time is known but the closing time is difficult to tell and they added that some demons take a long time to be cast out. Asked about the names of the parts of a worship service (Q9), many informants provided a list including five to 12 parts. It was found that related activities were given different names and what was considered as an accessory in one church was regarded as an essential part in another. An attempt is made here to group the names of related activities:

- Breakthrough/opening prayer

- Praise/worship/thanksgiving/adoration/exhortation

- Intercession/intercessory prayer/invocation

- Healing/deliverance/prophecy/anointing/chronicle of miracles/prophetic focus/prediction

- Testimonies/prophecy confirmation

- Tithes/offerings/offertory

- Gospel reading/reading of scriptures

- Preaching/Sermon/Message/Predication/divine liturgy

- Welcoming of visitors/altar call/first timers' announcement

- Announcements

- Closing prayer

Q10 inquired about the languages that were used in the worship service the informants had just attended. It turned out that, in all 35 churches, English and French were used: anything said in English was simultaneously put into French and vice versa. In a couple of churches, the pastors were French-English bilinguals and they alternated the use of these two languages throughout the worship services. However a few other languages were heard when certain activities-testimonies and prayers-were going on. During testimonies, language choice was determined by the person testifying; any language (including Pidgin English and indigenous languages) could be used and a translator systematically passed on the message in either French or English. Similarly, during prayers, tongue speaking was used by some pastors (e.g. "kabala kobokili gorabaka chikere") and translation was not provided. Asked why these languages were used, no answer was given. In short, language management in these churches is characterised by the joint use of two languages, French and English, with every message said in one language translated simultaneously into the other.

Q11 focused on the languages in which songs were executed and it was found that they were sung in French and English. Occasionally some lyrics in Nigerian languages were heard. Lastly, the informants were asked to comment on language use in their churches (Q12). They reported that French and English were the official languages of Cameroon and they were used to make sure that no faithful was left behind. It was expected that each congregant mastered either 
French or English and translation would facilitate understanding. This language policy, which is written nowhere, is well-established among Pentecostals. They seem to have chosen these two languages so as to claim that they are observing the language policy of Cameroon, which is French-English official bilingualism (Constable [20], Tchoungui [21], Echu [22], Kouega [23]). Just as indigenous languages are somewhat ignored in official business in Cameroon, so too are they overlooked in the language practices of these churches. They seem to be saying that even if there was a dominant Cameroonian ethnic group in their churches, they would maintain their current language policy.

\section{Conclusions}

This work considered language management in 35 "international" Pentecostal churches, using the structural-functional model of analysis. Four research questions were set to guide the study. The first took up the elements of worship service structure that were shared by these churches; the analysis revealed that they share many key elements including healing, prediction, deliverance, testimony, offerings, Gospel reading, preaching, announcements, welcoming of visitors, even though they use different names to refer to related activities. The second question checked what languages were chosen in Cameroon by these churches to realise these shared worship elements and what factors determined the choice of these languages in the multilingual context of Cameroon. The analysis disclosed that French and English, the joint official languages of Cameroon, were chosen, perhaps to show that they adhere to the country's official bilingualism policy. This adherence seems to be very strong; actually, just as Government had been ignoring indigenous languages in official transactions, so too have these churches excluded indigenous languages from their hidden language policy.

The third question checked what languages were chosen in similar churches in other countries to realise these same shared elements and it was found that first, most of these churches exist only in Cameroon and secondly, the few that exist in other countries used English singly or in combination with other languages. The last question focused on the international nature of these churches and a serious mismatch was uncovered: while the faithful believe that their churches are found in every country of the world, the pastors claim that their churches welcome members from all countries of the world. Needless to say, the use of the term "international" did not seem to influence language management in the practices of these churches in any way. The main contribution of the paper, which derives from the analysis of 35 tokens out of a total number which is un known, lies in the fact that it has clarified the meaning of the term "international" in the names of Pentecostal churches and has shown that there seems to be little relationship between the names of these churches and their language management practices.

\section{References}

[1] Spolsky, B. (2004) Language Policy. Cambridge University Press, Cambridge. 
[2] Dieu, M. and Renaud, P. (1983) Atlas Linguistique de l'Afrique Centrale: Le Cameroun [Linguistic Atlas of Central Africa: Cameroon]. ACCT, CERDOTOLA, DGRST, Paris/Yaounde.

[3] Chia, E. (1984) The Indigenous Languages of Cameroon. Annals of the Faculty of Letters and Social Sciences, 11, 143-159.

[4] Bitjaa-Kody, Z.D. (2003) Annuaire des Langues du Cameroun [Yearbook of Cameroonian Languages]. Editions du CERDOTOLA, Yaounde.

[5] Kouega, J.P. (2007) The Language Situation in Cameroon. Current Issues in Language Planning (CILP), 8, 3-93. https://doi.org/10.2167/cilp110.0

[6] Lewis, M.P., Simons, G.F. and Fennig, C.D. (Eds.) (2014) Ethnologue: Languages of the World. 17th Edition, SIL International, Dallas, Texas.

http://www.ethnologue.com

[7] Kouega, J.P. (2013) Camfranglais: A Glossary of Common Words, Phrases and Usages. Lincom Europa, Lincom, Muenchen.

[8] Kaplan, R. (2011) Macro Language Planning. In: Hinkel, E., Ed., Handbook of Research in Second Language Teaching and Learning, Routledge, New York, Vol. 2, 924-935.

[9] Shohamy, E. (2006) Language Policy: Hidden Agendas and New Approaches. Routledge, New York. https://doi.org/10.4324/9780203387962

[10] Spolsky, B. (2009) Language Management. Cambridge University Press, Cambridge. https://doi.org/10.1017/CBO9780511626470

[11] Spolsky, B. (2012) What Is Language Policy? In: Spolsky, B., Ed., The Cambridge Handbook of Language Policy, Cambridge University Press, Cambridge, 3-15. https://doi.org/10.1017/CBO9780511979026.003

[12] Kouega, J.P. (2008) Language, Religion and Cosmopolitanism: Language Use in the Catholic Church in Yaounde-Cameroon. International Journal of Multilingualism, 5, 140-153. https://doi.org/10.1080/14790710802152347

[13] Kouega, J.P. and Ndzotom, M.A.W. (2011) Multilingual Practices in Presbyterian Churches in Cameroon. International Journal of Innovative and Interdisciplinary Research, 1, 44-58. http://www.auamii.com/jiir/Vol-01/issue-01/X6.Kouega.pdf

[14] Kouega, J.P. and Baimada, F.G. (2012) Language Use in the Islamic Faith in Cameroon: The Case of a Mosque in the City of Maroua. Journal of Language and Culture, 3, 10-19. http://www.academicjournals.org/JLC

[15] Albakry, M.A. and Ofori, D.M. (2011) Ghanaian English and Code-Switching in Catholic Churches. World Englishes, 30, 515-532. https://doi.org/10.1111/j.1467-971X.2011.01726.x

[16] Myers-Scotton, C. (1997) Code-Switching. In: Coulmas, F., Ed., The Handbook of Sociolinguistics, Blackwell, Cambridge, MA, 217-237.

[17] Myers-Scotton, C. (2003) Code-Switching: Evidence of both Flexibility and Rigidity in Language. In: Dewaele, J.M., Housen, A. and Li, W., Eds., Bilingualism: Beyond Basic Principles, Multilingualism Matters, Clevedon, 189-203.

[18] Afutendem, L.N. (2015) Language Choice in Christian Denominations in the Northwest Region of Cameroon. Nka' Lumière: Revue Interdisciplinaire de la Faculté des Lettres et Sciences Humaines, Université de Dschang, 14, 75-91.

[19] Kouega, J.P. (2016) Language Practices and Religious Rites in the Full Gospel Mission Cameroon International Journal of Multilingualism, 13, 120-133.

[20] Constable, D. (1977) Bilingualism in the United Republic of Cameroon. English Language Teaching Journal, 29, 249-253. https://doi.org/10.1093/elt/XXXI.3.249 
[21] Tchoungui, G. (1983) Focus on Official Bilingualism in Cameroon: Its Relationship to Education. In: Koenig, E.L., Chia, E. and Povey, J., Eds., A Sociolinguistic Profile of Urban Centers in Cameroon, Cross Road Press, Los Angeles, 93-116.

[22] Echu, G. (1999) Le Bilinguisme Officiel au Cameroun: Critique et Perspectives. In: Echu, G. and Grundstorm, A.W., Eds., Official Bilingualism and Linguistic Communication in Cameroon, Peter Lang, New York, 189-201.

[23] Kouega, J.P. (1999) Forty Years of Official Bilingualism in Cameroon. English Today, 15, 38-43. https://doi.org/10.1017/S0266078400011251 


\section{Appendix 1}

List of the churches visited and the globalising terms in their names

*All nations

- All Family and Nations Outreaching Ministry

- Heaven's Gate of All Nations

- House of Prayer for all Nations (HOPFAN)

- Prayers for all Nations

*Global

- Eglise Frontière Globale

*International

- Breakthrough International Limited

- Christ Foundation Ministry International

- Christ Holy Church International (CHCI)

- Christian Missionary Fellowship International (CMFI)

- Christian Unity Ministries International

- Communauté Missionnaire Chrétienne Internationale

- Eglise Pentecôtiste du Cameroun Ministère International Va et Raconte ce que Dieu a Fait pour toi-Le Temple des Nations-Le Rocher Guidal (Pentecostal Church of Cameroon Ministry of International Go and Tell what God has Done for you-Nations Temple-The Rock Guidal)

- Faith Alive Ministries International

- Faith Covenant Ministry International

- God Almighty Prophetic Ministry International

- God's Stars International

- Kinship International Ministries

- Life Faith Ministry International

- Light World Mission International

- Lighthouse Chapel International

- Living Word Fellowship International-King's House

- Ministère de la Plénitude de Grâce Internationale

- Ministère International de la Montagne Sainte

- Ministère International Maison de Prière

- Restoration Centre Internatonal

- Resurrection Ministries International

- Sainte Eglise du Christ International

- Salvation Gospel Church International

- Triumphant Ministries International

- Vraie Eglise Internationale de Dieu du Cameroun

- World Mission Agency-Winners' Chapel International 
*Universal

- Universal Church of the Kingdom of God

*World

- Bethel World Outreach Ministries (BWOM)

- Living Faith Church World Wide

- World Mission Agency-Winners' Chapel International

- World Wide Mission

\section{Appendix 2}

Questionnaire/interview/observation (to be filled in by the research assistants)

I am a language student at the University and I want to find out how language is used in your church. I have a few questions to ask five members of your church. I have already met a church elder/the Pastor and I will be grateful if you could agree to be the next person.

I will jot down what you say and, at the end, I will read out what you have said to you. Later on, if you so wish, I will email to you the answers of the five people from your church.

1) How many chapels of this church are there in the city of Yaounde?

2) What is the hierarchical structure of the church i.e. who is above and below the pastor?

3) What are the various countries in which branches of this same church exist?

4) Do you have the addresses of this church in any two or more countries?

5) Do you organise meetings with other pastors of this church-be they monthly or annually?

6) Are the worship services conducted in all countries in the same way? In the same languages?

7) What does the term "international" in the name of your church mean to you?

8) How long does an ordinary worship service last in your church?

9) What are the most important parts of an ordinary service called?

10) In this church service that has just ended, what language was (languages were) used to realise Part 1 ? Why was this language (were these languages) used?

Part 1 Language(s) used

Motivation

Part 2 Language(s) used

Motivation

Part 3 Language(s) used 
Motivation

Part 4 Language(s) used

Motivation

11) In what language(s) did the choir(s) sing?

12) What comment can you make on the use of language in this church?

Thank you for your cooperation!

If you wish to get a copy of your church members' answers to these questions, do enter your email address here:

You can also contact your pastor, who will be given a hard copy of these answers. 